work was based on collections belonging to the Geological Survey of India. The collections in the Institute comprise those brought together by Prof. Sahni and his pupils in various parts of India, and others donated by institutions and colleagues abroad. They include many type specimens and other material described by Sahni and other members of the staff, and they are rapidiy increasing, thanks to the field activities which play an important part in the Institute's programme.

The scientific staff of the Institute consists at present of the director (Dr. O. A. Hoeg), two assistant directors (Dr. R. V. Sitholey and Dr. K. R. Surange), one senior scientific officer (post vacant), three junior scientific officers (lecturers), and a number of research scholars and research assistants. Nine scholarships have been granted by the Governments of India and of Uttar Pradesh and by the Assam Oil Company (Burmah Oil Co.). The scholars work on a wide variety of problems, most of them with the intention of submitting theses for the degree of Ph.D. at one of the Indian universities by which the Institute has been recognized.

The Council of Scientific and Industrial Research has sponsored three research schemes in the Institute, each scheme with two research assistants appointed by the Council and a senior member of the scientific staff as supervisor.

The administrative and clerical staff is quite considerable, and in addition there are an artist, a photographer, a mechanic, two section-cutters, and other assistant staff.

The scope of the Institute is to promote palæobotanical research in all its aspects, on an Indian, as well as international, basis. Necessarily, the study of Indian fossil floras will always form the main object of the activity.

Apart from a very few and poorly preserved plant remains from older periods, the oldest flora in India is the Lower Gondwana flora, with Glossopteris, etc., connected with the most important ooalfields in India. From the younger periods there is an extremely interesting Jurassic flora, mostly in an excellent state of petrification, in the Rajmahal Hills in Bihar, and there are remains of flowering plants, in equally good preservation, in the Deccan Intertrappean of early Eocene age. In addition, there are fossil plants in other places and from different ages. Research on a variety of such material is being carried out in the Institute.

In recent years microfossils, particularly pollen grains and spores, have become more and more important in palæobotany. It happens that they are preserved in great numbers in sediments where macrofossils are few or entirely missing, and they may therefore help to solve age problems in cases where other fossils have failed. It was in recognition of this fact that Prof. Sahni planned a search for microfossils in Indian sedimentary rocks containing no macrofossils and the age of which is uncertain. The plan received the support of the Council of Scientific and Industrial Research in 1947 and is still going on in the Institute.

Peat bogs and lake deposits with an abundance of pollen, like those of north-west Europe, are unknown in India, but even so there are some possibilities of pollen analysis of Pleistocene and older sediments, for example, in clays in Kashmir, some of which have proved to be rich in pollen, and possibly also in the plains. Until now, practically nothing has been known about pollen production of trees and other plants in India ; such knowledge forms part of the basis for pollen analysis, and the Institute therefore, in 1952, started an investigation of the pollen in the air at Lucknow. With the support of the C.S.I.R., palynological studies on a broader basis, and a pollen herbarium are now being started.

In 1952 the Institute, again with the support of the C.S.I.R., and in co-operation with the Fuel Research Institute, was able to start another research scheme, the palæobotanical investigation of Indian coals. Studies on microfossils in Indian coals have been going on in the Institute since 1949; but under the new scheme it is possible to give the work a broader basis and a wider scope. The work so far has been concentrated on analysing the contents of spores and pollen in various seams. When a sufficiently detailed knowledge has been gained of the various spore forms and their distribution it will be of interest to ascertain to what extent this knowledge can be used for correlation of coal seams. Such practical utilization has proved to be of considerable value in other countries and has also already in a few cases been tried with success in India.

Prof. Sahni himself scarcely had any higher wish for the Institute than that it should be regarded by every palæobotanist as a home and as a place where scientists, from all parts of the world, could come for research and exchange of ideas. $\mathrm{He}$ did not live to see that happen. Now, however, the Institute is established, its doors are open, and palæobotanists are welcome to fulfil the wish of its great founder.

\section{NATURE OF VIRUSES}

$T$ HE Society for Visiting Scientists is to be congratulated on holding yet another successful informal symposium-this time on the "Nature and Constitution of Viruses". A crowded meeting on May 5, under the chairmanship of Dr. A. S. McFarlane, listened to opening contributions from three leading international authorities in this field.

Dr. P. R. Lépine described the work going on at the Pasteur Institute, Paris, in the study of virus inclusion bodies. He adopted a predominantly morphological approach illustrated by electron micrographs of inclusions seen in rabbit myxoma (which is prevalent at present in France), fowl pox and rabies. He discussed the different types, noting particularly that some appear to consist solely of aggregates of elementary virus particles, whereas others are not uniform in composition. An extreme case of the latter is to be seen in the intracellular polyhedra which characterize some insect virus infections and which contain only a few per cent of virus. Generally, small virus forms or signs of virus particles about to divide were absent from his pictures.

Dr. R. W. G. Wyckoff (United States) also showed some striking electron micrographs, mainly of ultrathin tissue sections. In the chick chorio-allantoic membrane infected with influenza virus, rods and spheres can be seen at the periphery of infected cells having the dimensions and general appearance of the round and filamentous forms of the virus. The rods show definite indications of originating as finger-like protrusions of the cytoplasm of the host cell, and the spheres appear to originate by fragmentation of the rods. No rods or spheres can be seen inside the infected cells. Rous virus in tissue culture showed no cytoplasmic protrusions of the host cell; but 
pockets of elementary virus particles are present in the cytoplasm-not unlike some of the inclusions shown by Dr. Lépine. Vaccinia-infected chorioallantoic membrane, on the other hand, shows some peripheral protrusions in addition to the characteristic brick-shaped particles inside the infected cells. Early in the course of infection a few virus particles are present; but again no small or dividing forms can be seen. In a few cases, chains of particles of standard size can be seen. Pictures of bacteriophage suggest the separate formation of tails and empty heads at an early stage in 'phage production. These appear to arise de novo in the host cytoplasm, that is, unassociated with parent particles.

Mr. F. C. Bawden (Harpenden) defined virus as a name for the cause of a transmissible disease with no visible cause. What is studied in the laboratory is a fraction which contains the maximal infectivity in the minimal of chemical substance. In the 1930's the study of the plant viruses was carried out mainly by chemical isolations. Twelve viruses have been isolated in a state of homogeneity, and in pure chemical form all are ribonucleoproteins. They diffor among themselves in the ratio of protein to nucleic acid, and electron microscopy has shown differences in morphology. The nucleoprotein appears to be the essential multiplying portion of the virus; but in studying chemically purified fractions it is well to remember that much may have been lost in the purification processes. He reminded the audience, in this connexion, that the removal of a rabbit's ear or tail would be unlikely to affect its reproductive activity.

Mr. Bawden referred to the dark period following infection, when little or no virus is detectable in the cells, and which led him to favour the hypothesis that the virus changes the genetic character of its host. In the course of infection a number of other types of particle are produced besides virus; these have been variously named 'incomplete virus', soluble antigens, etc. No kind of particle has been shown to be the forerunner of any other type, and Mr. Bawden thought it was asking a lot of Nature to turn out millions of particles identical with one another.

In the lively discussion which followed, a great deal of interest was shown in the recent demonstration by Hershey and Chase that, following infection by bacteriophage, the protein shell of the infecting 'phage remains outside the infected bacterial cell, while the nucleic acid enters and is able to initiate virus production even if the protein shells are removed by shearing forces. Dr. R. Markham, in particular, said he was mystified as to how 'phage nucleic acid got into and out of its protein shell and whether the results would apply to other viruses. In a meeting where many interesting points were discussed, this topic seemed to appeal most to the general imagination.

Prof. S. P. Bedson pointed to an inconsistency in the argument about how viruses multiply. It is generally conceded that the rickettsiæ and the organisms (? viruses) of the psittacosis group multiply by binary fission; but a different form of multiplication is postulated for the smaller viruses. The main argument in favour of this hypothesis is that following infection of cells by one of the smaller viruses, there is a latent period during which little or no virus can be detected in the cells, followed by a sudden increase in the amount of detectable virus. However, recent experimental work indicates that organisms of the psittacosis group, large viruses such as those of myxoma and vaccinia, and indeed all viruses which have been studied, show a similar type of growth curve. Prof. Bedson argued that if psittacosis organisms multiplied by binary fission, there was no real reason why smaller viruses should not do so also, and the speakers were not prepared to dispute his argument.

Prof. Wilson Smith was sceptical of generalizations in the field of viruses and put forward some experimental evidence with the proviso that, so far as he knew, it applied to influenza virus and nothing else. In general, his evidence lent support to Dr. Wyckoff's view that the virus incorporated some part of the host cytoplasm in it. Heat-treated influenza $A$ virus crosses serologically with the $B$ virus, and the implication is that both forms have something in common derived from the host, or are contaminated by host protein. On the whole he favoured the former. Mr. Bawden countered with the statement that "one man's impurity is very often another man's biologically important product".

Dr. B. Stocker described the work of Zinder and Lederberg on 'phage transduction as supporting Wilson Smith's hypothesis. He pointed out that the factor which is transduced does not appear to be superficially situated on the transducing 'phage. $\mathrm{He}$ also described the behaviour of lysogenic 'phage as evidence that 'phage could be transmitted through different generations of bacteria in the complete absence of the usual structural characteristics.

Dr. A. Isaacs objected to the term fragments of cytoplasm when applied to viruses, and Bawden supported this and pointed to a competition between the cell and the virus for essential constituents.

Dr. McFarlane, in summing up, noted that a major part of the evening had been devoted to considerations of the influence of the host cell on the nature and constitution of the virus. This spontaneous trend, he said, suggests that the matter is of prime importance. Some speakers were prepared to go so far as to say that virus particles are shaped out of pieces of host cytoplasm-possibly out of whole genetic units-while others would only say that molecules with the specific antigenic configuration of the host are incorporated into viruses. A less vocal section of the audience appeared to resent these views and could see few grounds for believing that infecting virus particles did more than borrow some biochemical mechanisms from the host and get on with the job of self-duplication. Dr. McFarlane also remarked on the fact that the crystallographers present were prepared to confer 'crystal' status on the insect polyhedral bodies although these contained only a few per cent of virus. It seemed, therefore, that after crystals are isolated, the search must still go on for the ultimate virus particles.

\section{THE MUSEUMS ASSOCIATION ANNUAL CONFERENCE AT YORK}

$T$ HE fifty-ninth annual conference of the Museums Association was held at York during June 22-26 under the presidency of Dr. F. J. North, of the National Museum of Wales. It was on May 3, 1888, that museum curators from all parts of Britain were called by the Yorkshire Philosophical Society to discuss matters of common interest; and a further meeting, also at York, on June 20, 1899, witnessed the formation of the Museums Association. 